\title{
SOCIOLINGUISTIC MONITORING OF WORD USAGE FREQUENCY OF YOUTH SOCIOLECT ${ }^{1}$
}

\author{
Anna A. Petrova \\ Kazan Federal University, Kazan, Russia \\ Nadezhda A. Sytina \\ Volgograd State University, Volgograd, Russia \\ Elena S. Aleksandrova \\ Volgograd State University, Volgograd, Russia
}

\begin{abstract}
The current paper describes the lexical units of youth sociolect and is aimed at monitoring youth speech. Special attention is given to heterogeneous social factors that influence the word usage in youth sociolect and involve micro-and macrosociolinguistic pilot projects on frequency occurrence of English words in a multicultural society. Miscrosociolinguistic analysis was focused on societal and gender differences in youth sociolect. The initial stage of the macrosociolinguistic monitoring included the questionnaire development, setting the boundaries of a sociolinguistic survey and the number of lexical items under consideration. The second step in the project was monitoring itself. Finally, the results of the monitoring were analyzed. The study was carried out through an online questionnaire, face-to-face and remote interviewing, with native English speakers and speakers of other languages from different countries and regions. The monitoring of usage frequency demonstrated that a limited number of English lexical units are used in interpersonal and professional communication; the other part of words presents a diverse picture. The respondents involved in professional activity tend to demonstrate more tolerance to the youth sociolect than ordinary people. The analysis proved the point about the heterogeneous character of sociolect usage by youth and its dependence on the sphere of communication.
\end{abstract}

Key words: youth sociolect, micro- and macrosociolinguistic monitoring, frequency of word use, individual factors, social factors.

Citation. Petrova A.A., Sytina N.A., Aleksandrova E.S. Sociolinguistic Monitoring of Word Usage Frequency of Youth Sociolect. Vestnik Volgogradskogo gosudarstvennogo universiteta. Seriya 2. Yazykoznanie [Science Journal of Volgograd State University. Linguistics], 2020, vol. 19, no. 4, pp. 120-132. DOI: https://doi.org/10.15688/

Дата поступления статьи: 30.09.2019

ББК 81.006 .2 Дата принятия статьи: 28.04.2020

\section{СОЦИОЛИНГВИСТИЧЕСКИЙ МОНИТОРИНГ ЧАСТОТНОСТИ УПОТРЕБЛЕНИЯ СЛОВ МОЛОДЕЖНОГО СОЦИОЛЕКТА ${ }^{1}$}

\author{
Анна Александровна Петрова \\ Казанский (Приволжский) федеральный университет, г. Казань, Россия \\ Надежда Александровна Сытина \\ Волгоградский государственный университет, г. Волгоград, Россия \\ Елена Сергеевна Александрова \\ Волгоградский государственный университет, г. Волгоград, Россия
}


Аннотация. В статье рассматриваются лексические единицы молодежного социолекта с социолингвистической точки зрения. Прикладной аспект данной проблемы заключается в дифференцированном мониторинге молодежной речевой коммуникации. Вариативность употребления лексических единиц связана с неоднородностью социальной базы носителей языка, а также с индивидуальными факторами. В статье представлены результаты реализованных авторами микро- и макросоциолингвистических пилотных проектов. Микросоциолингвистическое исследование было посвящено гендерным особенностям употребления лексических единиц молодежного социолекта. На первом этапе реализации макросоциолингвистического проекта были сформированы анкеты, определены границы социолингвистического опроса и количество лексических единиц, подвергаемых мониторингу в поликультурном обществе; на втором этапе был проведен мониторинг; на третьем этапе был осуществлен анализ результатов мониторинга. Работа выполнена на основе онлайн-анкетирования и полевых исследований. Результаты мониторинга свидетельствуют о том, что использование английских слов молодежного социолекта в межличностной и профессиональной коммуникации имеет ограниченный характер. Респонденты (участники, занятые в профессиональной коммуникации) демонстрируют большую терпимость к английским словам молодежного сленга по сравнению с другими участниками общения. Полученные данные подтверждают гетерогенность употребления респондентами английских слов молодежного социолекта. Вклад авторов. Под руководством А.А. Петровой сформулирована концепция исследования, разработаны анкеты, проведен макросоциолингвистический мониторинг и обобщены полученные результаты. Н.А. Сытиной осуществлен микросоциолингвистический мониторинг, проанализированы и обобщены анкетные данные респондентов. Е.С. Александровой установлены особенности употребления английских слов молодежного социолекта с учетом индивидуальных и социальных факторов и обобщены результаты исследования.

Ключевые слова: молодежный социолект, микро- и макросоциолингвистический мониторинг, частотность употребления слова, индивидуальные факторы, социальные факторы.

Цитирование. Петрова А. А., Сытина Н. А., Александрова Е. С. Социолингвистический мониторинг частотности употребления слов молодежного социолекта // Вестник Волгоградского государственного университета. Серия 2, Языкознание. - 2020. - Т. 19, № 4. - С. 120-132. - (На англ. яз.). - DOI: https://doi.org/ 10.15688/jvolsu2.2020.4.11

\section{Introduction}

Recent decades have seen different research perspectives on analyzing the English influence on receptor languages that is resembled in publications in this country and abroad. The assimilation of English words by language system and individual consciousness are not similar processes, therefore it may be helpful to look at them as an element of social behavior. The words, serving as tools of social contacts, demonstrate secondary and non-verbal meanings. The linguistic behavior itself is deprived of social regulation but when it is involved in social symbolism based on symbolic forms, linguistic models gain additional interpretation, thus serving to distinguish social relations. We assume that English words are socioculturally marked lexical units in a receptor language that reflect the speaker's attitude to a loanword in the language, his / her status and gender as well. In other words, they may appear as an "admission ticket" to certain social groups of society. It is the youth who is mostly affected by the English language. Youth sociolect is often made of English lexemes, words that have been actively borrowed to the vocabulary of other languages. In the linguistic literature, the youth language is viewed as a specific one, opposed to the standard language. Many studies of the youth language address this topic as "youth jargon", "youth slang" or "interjargon", using these terms interchangeably. It is known that sociolect is a subcode with socially marked lexemes, which forms a codified subsystem of a certain social community. Recent research shows that the term "sociolect" refers to a social variety of language and is deprived of an evaluation function. The youth sociolect covers a wide range of speakers and it demonstrates the tendency to borrow words from various jargons [Anishchenko, 2010, p. 35]. This article adopts an understanding of "youth language" as a language variety, thus it is youth sociolect, which is characterized by individual and social parameters (age, social status, language competence, and gender). It should be noted that if a differentiated monitoring of the youth language is carried out regularly, it may confirm that social variability in adolescents' speech is not 
the only type of speech variation [Mihailova, Solnyshkina, 2017; Petrova, Sytina, Ergunova, 2019]. This heterogeneity is mainly related to the social background of young people. The regional variation of the youth language has so far received little attention. For example, M.A. Kropacheva conducted several experiments aimed at differentiating youth words used in conversation in some regional areas of Russia. According to the results of the survey, students living in different cities have a variable perception of slang words as the informants actualize in speech various meanings of the same word. Nevertheless, there is a certain unity in youth jargon on the entire territory of Russia as most meanings coincide and their frequency features are similar [Kropacheva, 2013]. This idea is confirmed by the research findings of A.V. Degaltseva [Degaltseva, 2013], which proved that most jargon words used by bank employees are the words of youth sociolect and computer jargon.

Changing linguistic situation in youth sociolects due to internalization and globalization of languages and cultures have spurred a lexicographical boom. On the one hand, it accounts for the seek to capture all language developments in dictionaries, on the other hand, this process is determined by external sociolinguistic causes, namely the growing role of various information sources, as well as an attempt to respond to language users requests.

The purpose of the paper is to monitor how youth sociolect speakers use English slang words, codified in dictionaries, taking into account individual and social factors. We assume that the complex language analysis calls for differential scientific and practical monitoring in the following key areas: a) sociolinguistic, monitoring the youth speech behavior from various perspective (age groups, regional linguistic variants, etc.); b) linguostylistic, studying the youth-specific lexicon, that is, socially marked language means, organized into the youth "novoyaz"; c) communicative and functional, investigating strategies and tactics of communication within youth communities; d) didactic, achieving the objectives related to developing the competent linguistic identity and teaching speech culture to young people.

The applied aspect of the issue under study is related to a differentiated approach to the youth speech monitoring. It involves the pilot experiment that focuses on the research theories or hypotheses about the youth language and development of an average linguistic identity. Moreover, the study provides data to consider some language-related problems, as follows: development of the dictionary, containing the most popular among youth word forms and lexemes, psycholinguistic assessment of linguistic norms in conversational interaction, as well as academic writing, a youth sociolect analysis in terms of new words creation and classification of lexical items (jargon words, neologisms, dialect words, etc.) from various perspectives.

This article presents the results of microand macrosociolinguistic monitoring of the frequency use of English words by youth sociolect speakers. The words are taken from the codified Dictionary of Youth Slang (English, German, French, and Russian Languages) [Rebrina et al., 2017] as well as English Slang dictionaries [Beale, ed., 1989; Nado li znat...].

The monitoring was carried out in two stages in the years 2014 to 2018 . The first stage included microsociolinguistic monitoring. It concerned the differences between gender and age of speakers in the use of English words. The second stage of the macrosociolinguistic monitoring was conducted between 2016 and 2018. Several individual factors (gender, age, the country of residence and language competence) as well as social factors (occupation and social status) were taken into account in the monitoring of most frequently used words of youth sociolect.

\section{Methods}

The study is based on the methods adopted in the area of macro- and microsociolinguistics: field study, questionnaire, face-to-face, and online interviewing, statistical data processing as well as methods of scientific description: observation, collection of information, interpretation, and classification. The analytical method of correlation is used to understand the links between dependent (linguistic factors) and independent (social factors) variables where such variables as age, education, social status, geographic distribution, and others are described in terms of quantity. 


\section{Discussion of results}

\section{Microsociolinguistic pilot project (2014-2016)}

This study treats anglicisms in the youth sociolect as agnonims, the words that are little understood or misunderstood by speakers whose languages are others than English [Morkovkin, Morkovkina, 1997]. This suggests that anglicisms, found at the periphery of linguistic consciousness, may serve as a code of identity in terms of social status as well as gender. Gender studies play a significant role in human sciences as they bring new perspectives on social development [Tannen, 1994]. It has been observed for a long time that speech production is sex-associated. Differences in male and female speech are reported in studies: [Goroshko, 1997; Günthner, 2001; Kotthoff, 2002; Lakoff, 1973]. Most studies in this area make use of the two paradigms, that of difference and that of dominance. The difference theory interprets male and female unlikeness due to the subcultural distinction. The second is associated with the idea of the subordination position of women in society [Skrynnikova, Astafurova, Aleksandrova, 2017]. A review of the scientific literature has revealed that there has been no empirical study of anglicisms in the gender perspective and this fact explains the choice of the topic of the article.

V.I. Grishkova [Grishkova, 2006] points out that the gender peculiarities of the youth language are characterized by the certain parameters (see Fig. 1).

Thus, following Grishkova's understanding of gender as a cognitive category, we assume that being a stable component, gender may influence a foreign word meaning experiences of a speaker.

The sociolinguistic study was conducted among the students of Volgograd State University as well as high school students. The study covered
15 full-time university students and 14 high school students. The target resource audience includes 18 females (62\%) and 11 males (38\%), aged 15 17 (45\%) and 18-20 (55\%). 20 English words of youth sociolect were analyzed. The Russian respondents were asked to provide answers to the following research questions (RQs):

RQ 1: Do you use English words in the speech in the Russian style? (always; often; sometimes; hardly ever; never).

RQ 2: In what spheres do you mostly use them? (parents; friends / peers; university / school).

RQ3: What anglicisms do you mostly use? (Choose from the given list).

According to the research, it was found out that, firstly, young people use anglicisms in their speech. The answers to the RQ1 and RQ2 provide that about $80 \%$ of university and high school students sometimes use English words in their speech and mostly in conversations with friends / peers. At the same time, $50 \%$ of respondents admit that they can do without anglicisms and use them as an index of prestige within a social group. Secondly, English loan-words demonstrate some peculiarities in terms of gender.

The results of the student audience survey are following. The reactions were classified according to nominations. Several semantic fields were revealed with a number of lexico-semantic groups. For example, both female and male university and higher school students use English words in the topics related to semantic field "human", subdivided into 5 semantic subclasses: 1) nomination of social groups: teaching staff тичер (teacher), representatives of the youth environment - гайз (guys), пипл (people); 2) personal relations: зафрендить (friend), $\mathrm{cu}$ стер (sister), бро (brother); 3) leisure activities and amusement: клаббиться (clubbing), денcumb (dance); 4) food and drink nominations: потатошка (potato), дринк (drink), фacm-

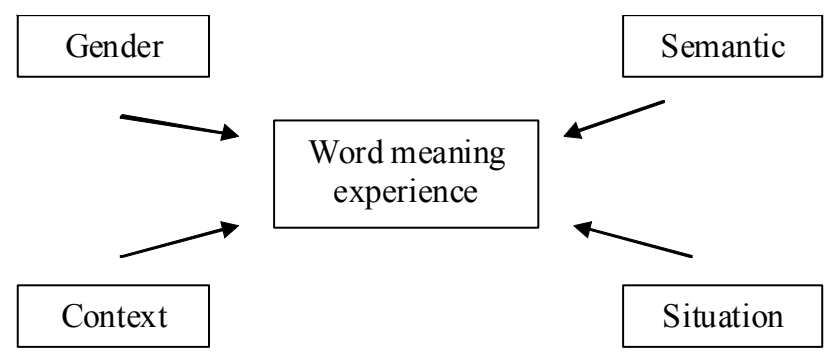

Fig. 1. Gender parameters 
фуд (fast food); 5) computer nominations: юзать (use), лайкать (like), заскринить (screen), зачекиниться (check in), зафолловить (follow), сделать сэлфи (selfie), банить (ban). As education is the main sphere of activity, it might be expected that the language of students will demonstrate anglicisms, characterizing the student life, spheres of social and practical activity. Contrary to expectation, based on the respondents' answer analysis, it is possible to conclude that there are few cases of such nominations, namely, nominations of the teaching staff, some subjects and activity nominations.

English loan-words demonstrate some peculiarities in terms of gender. The gender asymmetry is demonstrated in the number of lexical units used by the students. Females are more likely to use some few anglicisms and these words are mostly interjections and adjectives, "the evaluation words", expressing the attitude to the situation itself. For example, мей би (may be), вай нот (why not), in the situation when the partner does not agree with the suggestion. It confirms the fact that females tend to use more imperatives and phrases expressing uncertainty. As to the indicative of vocabulary diversity, female students demonstrate in their speech words related to life-style and appearance: лук (look), aymфum (outfit), мейк an (make up), бpa (bra). There are also words that describe interpersonal relations. For example, the word френдзонить characterizes the idea of getting apart but having friendly relations with the ex-partner. Moreover, female students are more creative in their style of communication, forming new words when an English element is used in combinations with some native elements, adding Russian inflectional suffixes to a borrowed English word. For example, отчетить is a blending of the Russian word oтчет, отчитаться and the anglicism from the computer discourse chat.

In contrast to female students, male students use lexical items which are found in computer games: daмaz (damage) - losses which a character suffers in a computer game, голда (gold) - money in computer games; some verbs: бафнуть (buff) - to improve the results or the features of a character; спойлернуть (spoil) to damage something, and vulgar words.

In the publication we have come across, some researchers claim that there are no language differences in the spoken speech of higher school and university students. As expected, the answers to the RQ1 and RQ2 show no significant difference in frequency and sphere usage of anglicisms among male and female university and higher school students. However, according to RQ 3, the study provides the evidence that male higher school students tend to use more English vulgar words and words from computer discourse in their speech as compared with those of university students. This suggests that they go through the stage of maturity and identification of social and gender roles. On the one hand, male higher school students seek status support as men; on the other hand, they are still teenagers, concerned with playing computer games. Thus, it encourages higher school students to use English words in their speech, as they appear to be the quickest and most accessible symbol of status and gender. Moreover, contrary to the stereotype, which suggests that females avoid using coarse language, there is evidence that masculinity sometimes predominates in female language and it affects the vocabulary of anglicisms used by female higher school students. For instance, there are social contexts when female higher school students use the phrase полный эбаут (about), driven to demonstrate equal status to men.

It may be concluded that the use of aglicisms is gender-sensitive due to psychological and social factors. Emotionality and vulnerability make females use more interjections and adjectives. Moreover, females demonstrate linguistic creativity that appears in combining English words with the words of the Russian language. Males, on the contrary, tend to use vulgar words of the youth sociolect, asserting their masculinity. Thus, the study revealed gender differences in the English word use, suggesting that female university and high school students tend to use English youth sociolect words in relation to the spheres of personal relationships, cosmetics, clothing, whereas male students tend to use more words related to computer technology.

\section{Macrosociolinguisctic pilot project (2016-2018)}

At present, there is a great deal of research that is concerned with studying the youth vocabulary in one language and comparing adolescents' speech with other age 
groups [Fishman, 1998; Kerswill, 1996]. Besides, there is a trend in composing youth slang dictionaries. However, data collection and macrolinguistic monitoring of English word use is a rare case. Thus, there is an urgent need comparing youth sociolect in various sociocultural contexts, identifying differences and similarities due to extra- and linguistic parameters. The applied aspect of this problem means differentiated monitoring of young people's speech and experimental checking of available research on some tendencies in youth speech as well as the development of average linguistic identity.

The study is based on works on sociolinguistics [Bogdanov, 1990; Krysin, 1976; et al.], evaluation theory [Arutyunova, 1988; Kubryakova, 1995; et al.], pragmatics [Lakoff, 1973; Searle, 2002; et al.] and youth language research [Beregovskaya, 1996; et al.]. It focuses on the lexical units from the English language, codified in the Dictionary of Youth Slang (English, German, French, and Russian Languages) [Rebrina et al., 2017]. The pilot project was developed for conducting some preliminary experiments with the goal to test the assumption that English words of the youth sociolect are used in common speech regardless of the speaker's place of residence, profession, gender and national identity. We also assume that some English words of the youth sociolect, represented in the dictionary [Rebrina et al., 2017], can be also used by elderly people.

The pilot experiment was carried out in the form of separate micro-experiments, including field studies (aimed at studying people's verbal behavior and conducted in their daily living conditions). Micro-experiments were performed through the following methods: English words of the youth sociolect were selected from the dictionary in alphabetical order by means of continuous sampling technique and each online questionnaire included not more than 20 words. A total of 32 microexperiments were conducted. This article presents the result of one micro-experiment and shows the general conclusions on the microexperiments as a part of the pilot project (there were 640 questionnaires with 20 English lexemes; each micro-experiment monitored 20 English words from 20 respondents).
The field study is applied to social experience in using English youth sociolect words when the massive internet interviewing as well as observing people in a contact interview are the only ways to get access to their experience. The field research involves leaving the office and observing people in their natural environment.

Following the field-study methods of Newman, the stages of the research include [Neuman, 1999]:

- choice of location and access to it (the Internet as a field platform, Google Forms and Survio for the internet interviewing);

- strategy of entering into the field: selfpresentation, distraction and understanding;

- observation and data collecting, researcher conclusions, and maps and diagrams which represent the field.

The present field survey does not include the issues related to concepts and concept spheres, therefore it does not provide a core-periphery study with the schemes of a certain thesaurus as, for example, the representation of the hierarchical concepts "human - nature" in the Sami language [Ivanishcheva, 2016].

The data were collected through online interviews. The survey was carried out on such websites as Google Forms and Survio. It included Native English speakers as well as speakers of other languages from different countries of residence (Poland, United Kingdom, Russia, Viet Nam, Yemen, Thailand, Belgium, Croatia, Bulgaria, Macedonia, Turkey, Germany, Algeria, USA, Greece, Egypt, Indonesia, Russia, United Kingdom and Korea). The first stage of the study involved the survey. The second step of the project included monitoring and the analysis of the results.

In the study 640 lexical units were considered and 640 people responded to the questionnaire: 293 females, aged 19 to 52 (45.8\%) and 347 males, aged 19 to 44 (54.2\%). The survey on the frequency of word use included several questions: 1) What is your gender?; 2) What is your age?; 3) Is English your native language?; 4) What is your country?; 5) Specify the field of activity (student / worker); 6) Where do you usually hear it?

The examples of male and female questionnaires with answers are given below (see Fig. 2 and 3). 
Where do you usually hear it? *

\begin{tabular}{|c|c|c|c|c|}
\hline & Internet & TV & $\begin{array}{c}\text { Everyday } \\
\text { commmunication }\end{array}$ & Nowhen \\
\hline Damp squib & $\square$ & $\square$ & $\square$ & $\nabla$ \\
\hline Deadbeat & $\square$ & $\nabla$ & $\square$ & $\square$ \\
\hline Deadpan (1) & $\square$ & $\nabla$ & $\nabla$ & $\square$ \\
\hline Deadpan (2) & $\square$ & $\nabla$ & $\square$ & $\square$ \\
\hline Deck & $\nabla$ & $\nabla$ & $\checkmark$ & $\square$ \\
\hline Dicey & $\square$ & $\nabla$ & $\square$ & $\square$ \\
\hline Dinero & $\square$ & $\square$ & $\square$ & $\checkmark$ \\
\hline Dinosaur & $\nabla$ & $\square$ & $\square$ & $\square$ \\
\hline Dirt & $\square$ & $\square$ & $\nabla$ & $\square$ \\
\hline Dirty & $\square$ & $\square$ & $\nabla$ & $\square$ \\
\hline Dodgy & $\square$ & $\square$ & $\nabla$ & $\square$ \\
\hline Dorky & $\square$ & $\square$ & $\nabla$ & $\square$ \\
\hline Drag queen & $\square$ & $\square$ & $\square$ & $\checkmark$ \\
\hline Duck soup & $\square$ & $\square$ & $\square$ & $\nabla$ \\
\hline Dude & $\checkmark$ & $\checkmark$ & $\nabla$ & $\square$ \\
\hline Dunno & $\checkmark$ & $\nabla$ & $\nabla$ & $\square$ \\
\hline Dynamite & $\nabla$ & $\nabla$ & $\nabla$ & $\square$ \\
\hline $\begin{array}{l}\text { Earbashing- } \\
\text { earbash }\end{array}$ & $\square$ & $\square$ & $\square$ & $\checkmark$ \\
\hline Earworm & $\square$ & $\square$ & $\square$ & $\checkmark$ \\
\hline Emoji & $\nabla$ & $\nabla$ & $\nabla$ & $\square$ \\
\hline
\end{tabular}

Fig. 2. Example of the male questionnaire 
Where do you usually hear it? *

\begin{tabular}{|c|c|c|c|c|}
\hline & Internet & TV & $\begin{array}{l}\text { Everyday } \\
\text { communication }\end{array}$ & Nowhere \\
\hline Damp squib & $\square$ & $\square$ & $\square$ & $\checkmark$ \\
\hline Deadbeat & $\square$ & $\square$ & $\square$ & $\checkmark$ \\
\hline Deadpan (1) & $\square$ & $\square$ & $\square$ & $\checkmark$ \\
\hline Deadpan (2) & $\square$ & $\square$ & $\square$ & $\checkmark$ \\
\hline Deck & $\checkmark$ & $\square$ & $\checkmark$ & $\square$ \\
\hline Dicey & $\square$ & $\square$ & $\square$ & $\checkmark$ \\
\hline Dinero & $\checkmark$ & $\nabla$ & $\square$ & $\square$ \\
\hline Dinosaur & $\checkmark$ & $\nabla$ & $\square$ & $\square$ \\
\hline Dirt & $\checkmark$ & $\nabla$ & $\square$ & $\square$ \\
\hline Dirty & $\nabla$ & $\nabla$ & $\square$ & $\square$ \\
\hline Dodgy & $\square$ & $\nabla$ & $\square$ & $\square$ \\
\hline Dorky & $\checkmark$ & $\nabla$ & $\square$ & $\square$ \\
\hline Drag queen & $\checkmark$ & $\nabla$ & $\square$ & $\square$ \\
\hline Duck soup & $\square$ & $\square$ & $\square$ & $\checkmark$ \\
\hline Dude & $\nabla$ & $\checkmark$ & $\square$ & $\square$ \\
\hline Dunno & $\square$ & $\square$ & $\square$ & $\checkmark$ \\
\hline Dynamite & $\square$ & $\square$ & $\square$ & $\nabla$ \\
\hline $\begin{array}{l}\text { Earbashing - } \\
\text { earbash }\end{array}$ & $\square$ & $\square$ & $\square$ & $\checkmark$ \\
\hline Earworm & $\square$ & $\square$ & $\square$ & $\nabla$ \\
\hline Emoji & $\checkmark$ & $\nabla$ & $\square$ & $\square$ \\
\hline
\end{tabular}

Fig. 3. Example of the female questionnaire 


\section{МАТЕРИАЛЫ И СООБЩЕНИЯ}

It should be noted that the field study demonstrates the results of both native English speakers and speakers of other languages in frequency usage, concerning individual (age, gender, language competence, and country of residence) and social factors (field of activity and area of work).

\section{Field study.}

The list of words for research.

- Damp squib (something which fails on all accounts, coming from the 'squib' (an explosive)).

- Deadbeat (totally exhausted or fatigued).

- Deadpan (1) (an expressionless face).

- Deadpan (2) (a person with an expressionless face).

- Deck (to hit someone).

- Dicey (unpredictable; risky).

- Dinero (money).

- Dinosaur (something old-fashioned or out of date).

- Dirt (extremely bad person).

- Dirty (offensive; pornographic).

- Dodgy (something wrong, illegal).

- Dorky (strange; peculiar). woman).

- Drag queen (a man who dresses like a to do).

- Duck soup (very easy; an easy thing

- Dude (a male).

- Dunno (contraction of "don't know").

- Dynamite (powerful; excellent).

- Earbashing - earbash (a non-stop chatter, or nagging, which is usually boring or annoying to others).
- Earworm (a melody or a portion of a piece of music that is involuntarily repeated in one's mind; an irritatingly catchy tune).

- Emoji (a small digital image or icon used to express an idea, emotion, etc., in electronic communication (text messages, emails)) [Rebrina et al., 2017, pp. 27-28].

A. English words and gender.

20 respondents were involved in the survey. Figure 4 shows the gender differences: 16 males $(80 \%)$ and 4 females (20\%).

Speech production is known to be sexassociated, and gender may influence the usage of English words of youth sociolect by a speaker. The male and female respondents demonstrate difference in frequency and sphere usage of English words of youth sociolect. Males tend to use English words in their speech more often. Moreover, it is noted that the use of English youth words by housewives is a rare case, compared with socially needed or employed females. It contributes to the fact of the social functions of English lexemes.

\section{B. English words and age.}

As for the age differences, the popularity of youth words decreases with age due to the fact that the expressive function associated with youth sociolect is not longer dominant for the elder generation. The primary users of English words are young people aged 19 to 28 . Young people are radical in every aspect of life and it encourages them to use English words of youth sociolect in their speech as they appear to be the quickest and most accessible symbol of a group membership. The results of the field study and data processing from questionnaires make it possible to conclude that the

\section{What is your gender?}

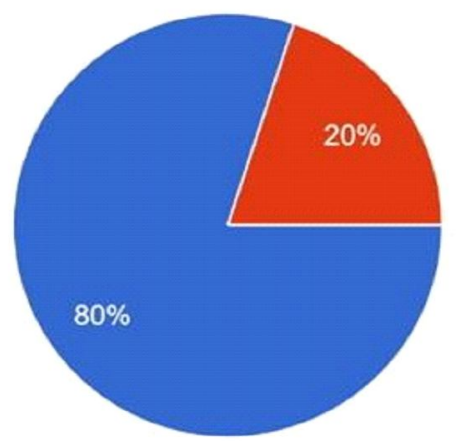

Fig. 4. Gender differences 
increase in the use of English word at 20 is followed by the decrease forwards 28 . So, as people are getting old, their passion for English words is becoming less. This trend is evident in Figure 5 where the horizontal line shows the age of respondents and the vertical one demonstrates the number of people who participated in the survey (Fig. 5).

C. English words and language competence.

The third question in the questionnaire relates the language competence. Comparing the cases of an English word, used by native English speakers and respondents who speak other languages than English, it is possible to note certain diversity. The spheres of usage reported by native English speakers are not the same as marked by respondents with other languages. It can be explained by their relative knowledge or lack of knowledge of a word use sphere, its semantic diversity (a lexical unit can demonstrate a semantic change of meaning different from the meaning in the language other than English) and the degree of a word novelty (a speaker of some other language with some English language proficiency cannot be familiar with a word).

D. English words and country of residence.

The study shows that the country of residence does not influence the use of English words of youth sociolect. This microproject involves respondents from 9 countries, as follows: Bolivia, China, France, Mexico, New Zealand, Russia, Sweden, USA and United Kingdom. The questionnaire data provide evidence for the fact that English words of youth sociolect are used by people from various countries. Due to the influence of global youth cultures and media as well as the Internet, English words of youth sociolect are gaining popularity, regardless of the country of residence and the most frequently used words are practically the same in these countries.
E. English words and field of activity.

Question 5 was about the field of activity (worker / student): out of 11 respondents (55\%) $4(20 \%)$ reported being students, $2(10 \%)$ - both student and worker; $1(5 \%)$ was a student who worked part-time; there was also a college student and one person who neither worked or studied.

F. English words and area of work.

The last question of the questionnaire about the area of work is optional for the respondents due to the previous question about the field of activity: $22.2 \%$ - marketing; $11.1 \%$ - design of architecture studio, communication, construction, customer service, project manager (55.5\%); $22.2 \%$ do not work.

Generally speaking, there is an inverse correlation between the field of activity (the area of work) and acceptance of the words of youth sociolect. The higher professional training of a respondent is the more the tolerance he/ she demonstrates to English words of youth sociolect. The sphere of word use ranges from everyday communication to specialized topics in professionally-related communication [Petrova, Sytina, Ergunova, 2019]. Moreover, there are lexical units that are used by most respondents, and some English words of youth sociolect are not used at all. Thus, English words in different languages perform a double function as a sign of group membership; most interactions take place among friends and acquaintances.

The Table demonstrates the spheres where the English words are most and less frequently used.

Taking into account the use of the youth words, monitoring has demonstrated that $20 \%$ of 640 lexical units are regularly used by the respondents. $80 \%$ of English words have shown

\section{What is your age?}

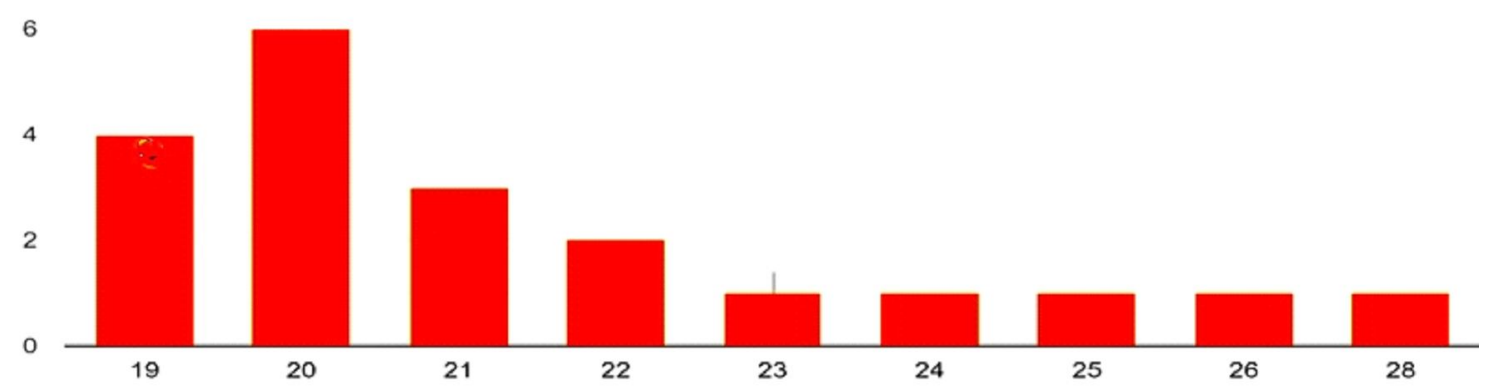

Fig. 5. Respondent age 


\section{Frequency of word usage}

\begin{tabular}{|l|l|l|}
\hline \multicolumn{1}{|c|}{ Word } & \multicolumn{1}{c|}{$\begin{array}{c}\text { Most frequently } \\
\text { used spheres }\end{array}$} & \multicolumn{1}{|c|}{$\begin{array}{c}\text { Less frequently } \\
\text { used spheres }\end{array}$} \\
\hline Damp squib & Don't use & Work \\
\hline Deadbeat & Friends and don't use & Home \\
\hline Deadpan (1) & Don't use & Home, work and other \\
\hline Deadpan (2) & Don't use & Home, work and other \\
\hline Deck & Friends & Work \\
\hline Dicey & Friends & Work \\
\hline Dinero & Friends & Other \\
\hline Dinosaur & Friends & Work \\
\hline Dirt & Friends & Work and other \\
\hline Dirty & Friends & Don't use \\
\hline Dodgy & Friends & Other \\
\hline Dorky & Friends & Home and work \\
\hline Drag queen & Friends & Work \\
\hline Duck soup & Don't use & Work \\
\hline Dude & Friends & Work \\
\hline Dunno & Friends & Work \\
\hline Dynamite & Friends & Work and other \\
\hline Earbashing - earbash & Don't use & Work \\
\hline Earworm & Don't use & Work \\
\hline Emoji & Friends & Don't use \\
\hline
\end{tabular}

variations in their usage: some lexical units are not completely used / perceived / understood, while the rest of them are rarely used / perceived / understood. In some cases, the respondents (mostly native English speakers) identified the word, but it was marked as unknown.

Thus, there is certainly diversity in the use of English words by the people from different countries. It is confirmed by the survey, involving 608 people under 52 . The results of the research make it possible to conclude the dynamics of occurrence and usage of youth words of the English language. The most popular sphere of word usage is friendly-related communication. Nevertheless, it should be noted that some words are not used. This means that English words of youth sociolect are restricted in their use. Moreover, some words of the youth sociolect have become obsolete.

\section{Conclusion}

Summarizing the results of the survey, we find it possible to conclude that the frequency of using English words is influenced by individual factors: gender differences, the age of a respondent, the country of residence, the language competence, and social factors as the sphere of activity and social status. Certainly, the questionnaires of young people of the same age, the country of residence, the sphere of activity and language competence will vary (see Fig. 2 and 3). Thus, corresponding to the sphere of communication, a young person can be the bearer of various sociolects, which makes a "common youth jargon" understood by all young people regardless of their individual and social factors.

The present article shows the relevance of studying youth language in its functional environment. It should be noted that this kind of research is a rare case, mainly, English words manifestation has been given attention in fiction, mass-media, the Internet, in other words, multimedia sources. Therefore, this pilot study is an attempt to cover global and macro-sociological space of English words functioning, taken from certain dictionaries. Finally, it indicates the necessity to provide the monitoring of word use in common speech, identifying particular themes and providing transcripts as future-oriented research.

\section{NOTE}

${ }^{1}$ This research was financially supported by the Russian Government Program of Competitive Growth of Kazan Federal University. 


\section{REFERENCES}

Anishchenko O.A., 2010. Genezis i funktsionirovanie molodezhnogo sotsiolekta $v$ russkom yazyke natsionalnogo perioda [Genesis and Functioning of Youth Sociolect in the Russian Language of the National Period]. Moscow, Flinta Publ., Nauka Publ. 278 p.

Arutyunova N.D., 1988. Tipy yazykovykh znacheniy: Otsenka, sobytie, fakt [Types of Linguistic Meanings: Evaluation, Event, Fact]. Moscow, Nauka Publ. 339 p.

Beregovskaya E.M., 1996. Molodezhnyy sleng: formirovanie i funktsionirovanie [The Youth Slang: Formation and Functioning]. Voprosy yazykoznaniya [Topics in the Study of Language], no. 3, pp. 32-41.

Bogdanov V.V., 1990. Rechevoe obshchenie: pragmaticheskie i semanticheskie aspekty [Verbal Communication: Pragmatic and Semantic Aspects]. Leningrad, LGU. 90 p.

Degaltseva A.V., 2013. Nekotorye osobennosti i printsipy upotrebleniya zhargonnoy leksiki $\mathrm{v}$ elektronnom delovom obshchenii [Some Specific Features and Causes for Using Jargon Words in Electronic Business Communication]. Tezisy mezhdunarodnoy konferentsii "Stratifikatsiya natsionalnogo yazyka $v$ sovremennom rossiyskom obshchestve" (Sankt Peterburg 30 oktyabrya -2 noyabrya) [Proceedings of the International Conference on Stratification of National Language in Modern Russian Society (Saint Petersburg, October 30 - November 2)]. Saint Petersburg, Zlatoust Publ., pp. 61-66.

Fishman P., 1998. Conversational Insecurity. Cameron D., ed. The Feminist Critique of Language: A Reader. London, Routledge, pp. 243-260.

Goroshko E.I., 1997. Teoreticheskoe sostoyanie problemy polovoy dikhotomii $\mathrm{v}$ verbalnom povedenii [The Theoretical State of the Problem of Gender Dichotomy in Verbal Behaviour]. Verbalnye i neverbalnye deyksisy maskulinnosti $i$ feminnosti [Verbal and Nonverbal Deixis of Masculinity and Femininity]. Krivoy Rog, MITs ChYaKP, pp. 24-100.

Grishkova V.I., 2006. Proyavlenie gendernogo faktora v molodezhnom zhargone [Gender Pecularities of Youth Jargon]. Vestnik Rossiyskogo universiteta druzhby narodov. Seriya: Voprosy obrazovaniya: yazyki i spetsialnost [Bulletin of Peoples Friendship University of Russia. Series: Problems of Education: Languages and Speciality], no. 1 (3), pp. 53-56.

Günthner S., 2001. Die kommunikative Konstruktion der Geschlechterdifferenz: sprach-und kulturvergleichende Perspektiven. Muttersprache, vol. 111, no. 3, pp. 205-291.

Ivanishcheva O.N., 2016. Saamskiy yazyk: sokhranenie yazyka $v$ epokhu globalizatsii: monografiya [Sami Language: The Preservation of the Language in an Era of Globalization]. Moscow, Berlin, Direkt-Media Publ. 136 p. URL: https://books.google.de/books?id=YeJfDw A A Q B A J \& p g = PA $115 \& 1$ pg = PA 115 $\& \mathrm{dq}=$ характеристика+и+ядро+поля+в+ полевых + исследователях \&source=bl\&ots= 7Or3a2QXeb\&sig=ACfU3 U0yud8 LH TrOUa7iGhq 6 ynlv68 $\mathrm{NaQ} \& \mathrm{hl}=$ ru\&sa $=$ X\&ved $=$ 2ahUKEwjkxMjx8rLpAhVFyqQKHTbbDg YQ6AEwC3oECAYQAQ\#v=on epage\& $\mathrm{q}=$ характеристика\%20и\%.

Kerswill P., 1996. Children, Adolescents and Language Change. Language Variation and Change, vol. 8, iss. 2, pp. 177-202. DOI: https://doi.org/ 10.1017/S0954394500001137.

Kotthoff H., 2002. Was heist eigentlich "doing gender?" Wiener Slawistischer Almanach, Sonderband 55, pp. 1-27. URL: https://www. projektwerkstatt.de/media/text/gender download_doinggender2002.pdf.

Kropacheva M.A.A., 2013. Regionalnoe varyirovanie molodezhnogo zhargona s tochki zreniya chastotnykh kharacteristik leksicheskikh edinits (na primere studencheskogo zhargona g. Glazova i g. Sankt-Peterburga) [Regional Variation of Youth Jargon in Terms of Frequency of Lexical Units (In Case of Students Jargon of Glazov City and Saint Petersburg]. Tezisy mezhdunarodnoy konferentsii "Stratifikatsiya natsionalnogo yazyka $v$ sovremennom rossiyskom obshchestve" (Sankt-Petersburg 30 ortyabrya -2 noyabrya) [Proceedings of the International Conference on Stratification of National Language in Modern Russian Society (Saint Petersburg October 30 - November 2)]. Saint Petersburg, Zlatoust Publ., pp. 91-96.

Krysin L.P., 1976. Rechevoe obshchenie i sotsialnye roli govoryashchikh [Verbal Communication and Social Roles of Speakers]. Sotsialnolingvisticheskie issledovaniya [Socio-Linguistic Research]. Moscow, Nauka Publ., pp. 42-52.

Kubryakova E.S., 1995. Evolyutsiya lingvisticheskikh idey vo vtoroy polovine XX veka [Evolution of Linguistic Ideas in the Second Half of the $20^{\text {th }}$ Century]. Stepanov Yu.S., ed. Yazyk $i$ nauka kontsa XX veka: sb. st. [Language and Science in the Late $20^{\text {th }}$ Century. Collection of Articles]. Moscow, Izdatelskiy tsentr RGGU, pp. 144-238.

LakoffR., 1973. Language and Womans Place. Language in Society, vol. 2, no. 1, pp. 45-80. 


\section{МАТЕРИАЛЫ И СООБЩЕНИЯ}

Mihailova M.A., Solnyshkina M.I., 2017. Photographers Nomenclature Units: A Structural and QuantitativeAnalysis. Journal of History Culture and Art Research, vol. 6, no. 5, pp. 166-172. DOI: http://dx.doi.org/10.7596/taksad.v6i5.1266.

Neuman L., 1999. Polevoe issledovanie [Field Research]. Sotsiologicheskie issledovaniya [Sociological Studies], no. 4, pp. 110-121. URL: http://ecsocman.hse.ru/data/763/784/1217/ 015_nyuman_Sotsiologiya_za_rubezhom_1.pdf.

Petrova A.A., Sytina N.A., Ergunova O.T., 2019. Professionally-Related Common Communication: Sociolinguistic Monitoring of Most Frequently Used Words of Youth Sociolect. IOP Conference Series: Materials Science and Engineering. Vol. 483. The I International Scientific Practical Conference "Breakthrough Technologies and Communications in Industry" (20-21 November, Volgograd, Russia). DOI: 10.1088/1757-899X/483/ $1 / 012014$.

Searle J., 2002. Consciousness and Language. Cambridge, Cambridge University Press. $267 \mathrm{p}$.

Skrynnikova I.V., Astafurova T.N., Aleksandrova E.S., 2017. Mass Media Discourse Deployment and Its
Gender Specificity: Sociolinguistic Perspective. XLinguae, vol. 10, iss. 3, pp. 300-311.

Tannen D., 1994. Gender and Discourse. Oxford, Oxford University Press. 216 p.

\section{DICTIONARIES}

Beale P., ed., 1989. A Concise Dictionary of Slang and Unconventional English: From a Dictionary of Slang and Unconventional English by Eric Partridge. London, Routledge. XXVI, 534 p. Morkovkin V.V., Morkovkina A.V., 1997. Russkie agnonimy (slova, kotorye my ne znayem) [Russian Agnonims (Words That We Do Not Know)]. Moscow, Astra sem Publ. 195 p.

Nado li znat molodezhnyy sleng [Whether One Should Know Youth Slang]. EnglishFull.ru. URL: http:/ /englishfull.ru/znat/angliysky-sleng.html.

Rebrina L.N., Alekseenko D.S., Anepir E.R. et al., 2017. Slovar molodezhnogo slenga (na materiale angliyskogo, nemetskogo, frantsuzskogo $i$ russkogo yazykov) [Dictionary of Youth Slang (English, German, French, and Russian Languages)]. Volgograd, Izd-vo VolGU. 384 p.

\section{Information About the Authors}

Anna A. Petrova, Doctor of Sciences (Philology), Associate Professor, Leading Researcher, Research Laboratory “Intellectual Technologies of Text Management”, Kazan Federal University, Kremlevskaya St, 18, 420008 Kazan, Russia,AnnaAlePetrova@kpfu.ru, petrova16@mail.ru, https://orcid.org/0000-0003-4322-1324

Nadezhda A. Sytina, Candidate of Sciences (Philology), Associate Professor, Department of Germanic and Romance Philology, Volgograd State University, Prosp. Universitetsky, 100, 400062 Volgograd, Russia, n.sytina@volsu.ru, https://orcid.org/0000-0001-8247-6157

Elena S. Aleksandrova, Candidate of Sciences (Philology), Associate Professor, Department of English Philology, Volgograd State University, Prosp. Universitetsky, 100, 400062 Volgograd, Russia, e.aleksandrova@volsu.ru, https://orcid.org/0000-0001-5445-0048

\section{Информация об авторах}

Анна Александровна Петрова, доктор филологических наук, доцент, ведущий научный сотрудник НИЛ «Интеллектуальные технологии управления текстами», Казанский (Приволжский) федеральный университет, ул. Кремлевская, 18, 420008 г. Казань, Россия, AnnaAlePetrova@kpfu.ru, petrova16@mail.ru, https://orcid.org/0000-0003-4322-1324

Надежда Александровна Сытина, кандидат филологических наук, доцент кафедры германской и романской филологии, Волгоградский государственный университет, просп. Университетский, 100, 400062 г. Волгоград, Россия, n.sytina@volsu.ru, https://orcid.org/0000-0001-8247-6157

Елена Сергеевна Александрова, кандидат филологических наук, доцент кафедры английской филологии, Волгоградский государственный университет, просп. Университетский, 100, 400062 г. Волгоград, Россия, e.aleksandrova@volsu.ru, https://orcid.org/0000-0001-5445-0048 